\title{
Information needs and barriers to information sources by open and distance learners: A case of Mzuzu University, Malawi
}

\begin{tabular}{|c|c|}
\hline \multicolumn{2}{|c|}{$\begin{array}{l}\text { Authors: } \\
\text { Winner D. Chawinga }{ }^{1} \\
\text { Paxton Zozie }^{2}\end{array}$} \\
\hline \multicolumn{2}{|c|}{$\begin{array}{l}\text { Affiliations: } \\
{ }^{1} \text { Department of Library and } \\
\text { Information Science, Mzuzu } \\
\text { University, Malawi }\end{array}$} \\
\hline \multicolumn{2}{|c|}{$\begin{array}{l}{ }^{2} \text { Centre for Open and } \\
\text { Distance Learning, } \\
\text { Mzuzu University, Malawi }\end{array}$} \\
\hline \multicolumn{2}{|c|}{$\begin{array}{l}\text { Corresponding author: } \\
\text { Winner Chawinga, } \\
\text { winnchawinga@gmail.com }\end{array}$} \\
\hline \multicolumn{2}{|c|}{$\begin{array}{l}\text { Dates: } \\
\text { Received: } 29 \text { Apr. } 2015 \\
\text { Accepted: } 19 \text { Nov. } 2015 \\
\text { Published: } 08 \text { June } 2016\end{array}$} \\
\hline \multicolumn{2}{|c|}{$\begin{array}{l}\text { How to cite this article: } \\
\text { Chawinga, W.D. \& Zozie, P., } \\
2016 \text {, 'Information needs and } \\
\text { barriers to information } \\
\text { sources by open and distance } \\
\text { learners: A case of Mzuzu } \\
\text { University, Malawi', } \\
\text { South African Journal of } \\
\text { Information Management } \\
\text { 18(1), a692. http://dx.doi. } \\
\text { org/10.4102/sajim.v18i1.692 }\end{array}$} \\
\hline \multicolumn{2}{|c|}{$\begin{array}{l}\text { Copyright: } \\
\text { (C) 2016. The Authors. } \\
\text { Licensee: AOSIS. This } \\
\text { is licensed under the } \\
\text { Creative Commons } \\
\text { Attribution License. }\end{array}$} \\
\hline \multicolumn{2}{|l|}{ Read online: } \\
\hline 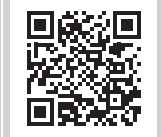 & $\begin{array}{l}\text { Scan this QR } \\
\text { code with your } \\
\text { smart phone or } \\
\text { mobile device } \\
\text { to read online. }\end{array}$ \\
\hline
\end{tabular}

Background: The Centre for Open and Distance Learning at Mzuzu University was established in 2006 with the aim to increase and broaden access to higher education to most Malawians who despite meeting entry requirements into higher education were not selected because of shortage of space on campus and other learning and teaching resources. Although Open and Distance Learning (ODL) is hyped as a practical option for making higher education available to many people as widely reported in the literature, universities need to address several issues for it to hold its ground.

Objectives: The study set out to investigate information needs and barriers to information sources by ODL students by addressing three objectives, namely information needs of ODL students, information sources of ODL students and challenges that ODL students face when seeking information for their courses of study.

Method: A survey questionnaire with a mix of closed-ended and open-ended questions was distributed to 350 students to find out the information sources and challenges that the ODL students face when searching for information to accomplish their academic activities.

Results: According to the findings, all $258(100 \%)$ students who answered the questionnaire need information to prepare for the end-of-semester examinations. Information sources that are used most by students include lecture notes, Internet and library books with scores of 238 (92.6\%), $207(80.5 \%)$ and $199(77.4 \%)$, respectively.

Conclusion: ODL students have limited access to information materials for accomplishing their academic activities and Mzuzu University can resolve this challenge by introducing satellite information centres in the three geographical regions of Malawi.

\section{Introduction}

Open and Distance Learning (ODL) is a subset of the discipline of education where the 'learner and the teacher are separated by distance' (Teaster \& Blieszner 1999). This concept is interchangeably referred to as 'correspondence education, home study, independent study, external studies, continuing education, learner centred education, distance learning, flexible learning and distributed learning' (Commonwealth of Learning 2002). Previously, the main clients of distance education were people who had jobs, such as those working in the military (Ohene \& Essuman 2014:159). However, universities are overwhelmed by the number of candidates applying for university education in recent times and this has forced them, across the globe, to become 'open' by admitting even people who are not currently working, and according to Ohene and Essuman (2014:159), this concept has implications for Africa. One may therefore argue that ODL is seen as a possible cost-effective and efficient way of making higher education available to many deserving individuals in the world, thereby contributing to an increase in human resource development. At the Open University in United Kingdom, which has led the way and no doubt set the standards for ODL, the true meaning of 'open' according to Gourley and Lane (2009:57) is that the institution has no barriers to entry and no entry requirements - only exit standards; a person's background and previous advantage or disadvantage are entirely irrelevant. In Africa, particularly in Lesotho, Boadi and Letsolo (2004) report that after the University of Lesotho noticed it had limited capacity to admit a large number of applicants with necessary entry requirements on full-time basis, the University opted to introduce ODL programmes as extended educational facility.

Previously, the assumption was that ODL programmes could be efficiently offered for arts subjects only but it is understood that the use of audio and video recordings, laboratory kits, computer programmes, telephone contacts and other media have proved that other subjects are teachable 
and learnable at a distance (Holmberg 2005:14). Even some aspects of medicine and surgery have proved to be subjects suitable for this form of education (Holmberg 2005:14). With advancements in Information and Communication Technologies (ICTs), especially Internet technologies in modern times (Chimpololo 2010:69), ODL programmes have their scope and parameters developed overwhelmingly and rapidly. Mazza and Dimitrova (2003:279) make it very clear that computing technologies such as Course Management Systems that support the development and the delivery of distance learning courses over the Internet are widely exploited nowadays. Aslam (2000:309) postulates that the major advantage of open learning systems has been their potential to provide an alternative mechanism (other than through the conventional training system) to reach a vast number of learners scattered across the globe. The ODL systems have capabilities to reach out to as many learners as possible at the same time whilst ensuring that quality is not compromised (Chimpololo 2010:69). The systems are very flexible, implying that they easily accommodate the varying learner pace, learning habits and learner convenience. This is critical especially considering that some learners might be employed, others may have social responsibilities and others may only afford tuition (they cannot manage to pay for other costs such as accommodation, transport and stipend as is the case with campus-based studies). For example, Zozie et al. (2004) find that in Malawi, a good number of prospective students have opted to study by distance mainly because of family commitments, financial constraints and inadequate space in universities.

One aspect that has been a point of concern with regard to the implementation of ODL programmes is the availability of relevant information to students. For example, Kavulya (2004:18) argues that most university library services were designed to meet the needs of on-campus programmes, and in most cases, they are not suited for ODL students. Thus, some researchers (Boadi \& Letsolo 2004; Jagannathan 1998; Oladokun 2014; Oladokun \& Aina 2009) have endeavoured to research the information needs of ODL students where various aspects such as their information needs, information sources and the challenges that they face have been addressed. In this study, we investigated similar issues (information needs, information sources and the challenges in ODL) but with a focus on the Malawian context. According to Chimpololo (2010:69), many opportunities exist in Malawi for the development of open and distance education as follows:

- An increased number of Malawians seeking higher education;

- Government's political will to invest in tertiary education: According to Chimpololo (2010:69), education is reiterated both in the Malawi Growth and Development Strategy and the Malawi Vision 2020 as a priority amongst priorities;

- Booming of ICTs: Malawi's sole ground telephone operator, the Malawi Telecommunications Limited has installed a Fibre Optic Cable worth US\$50 million, which has connected Malawi to the outside world through the World Wide Web at speeds never conceived before (Chimpololo 2010:70; Chisa 2006:25); and

- Rural electrification: Though in infancy stage, the Malawi Government is carrying out a rural electrification programme as part of the Malawi Growth and Development Strategy. Only a fraction of rural trading centres have already benefited from this programme but more are on the line.

However, despite all the potentials of ODL in Malawi, there seems to be no empirical study that has dealt with the information needs of this category of students. The current study is conducted to bridge gap.

\section{The concepts of information need and information seeking}

Information is needed in all stages of human development (Boadi \& Letsolo 2004:190). People need information for different purposes such as for entertainment, medical reasons, educational reasons and many more. It is not a direct and straight forward exercise for individuals to find and retrieve the required and relevant information. In fact, one has to spend time and apply enough energy and skills to find relevant information. Some researchers, such as O'Brien (1996), have put forward characteristics of quality information. Relevance, accuracy, timeliness, currency, completeness, clarity and cost-effectiveness are some such qualities of good information according to O'Brien (1996). The fact is if an individual has quality information, he or she becomes certain and knowledgeable about his or her problem. In other words, quality information helps individuals solve their problems. In principle, it is the need to solve a task that stimulates individuals to seek information (Wilson 1999:257). If there is no need to solve a task, it means there is no problem requiring a solution and it follows that one may not need information. Literature suggests that the way individuals seek and use information is what researchers call informationseeking behaviours. Information-seeking behaviour is actually 'the manner individuals articulate their information needs, search, recognise, retrieve and use information' (Oladokun 2014:304). For many years, user studies in libraries focused on the information retrieval systems that represented documents and texts through which users could use to retrieve the required information. However, Borgman (1984), Belkin and Vickery (1985) and Kuhlthau (1991:362) indicate that there has been a shift in focus from concentration on document or textual representations and search techniques to the study of users in information-seeking situations. Thus, in the past three decades, there has been a paradigm shift from studying information systems to studying the user needs and their information-seeking behaviour. It is well documented in the literature that attempts are increasingly being made by researchers to understand the holistic experience of information-seeking behaviour from the users' experience by focusing on their information needs: how they seek, identify, retrieve and use the information in addition to the problems that they face in accessing this information 
(Kuhlthau 1991:362). Similarly, the study attempts to investigate the information needs of ODL students at Mzuzu University (MZUNI) and challenges that they face in seeking information for their academic activities.

\section{MZUNI: Centre for Open and Distance Learning}

In Malawi, ODL is a relatively new concept in tertiary institutions because previously, it was only practised at the secondary school level (Chimpololo 2010:69). In order to address the issue of limited access to university education in Malawi, the Malawi Government through the 1997 Act of Parliament, established MZUNI, which became a second national University after the University of Malawi. Since its first intake in 1999, the University has steadily grown from a single Faculty of Education to four more faculties and three centres. One of the centres is the Centre for Open Distance Learning through which the University offers distance education to quite a good number of Malawians. According to Chimpololo (2010:69) and Mzuzu University (2014), the Centre (CODL) was established in July 2006 to plan, prepare and coordinate offering of programmes through the ODL delivery mode with the sole aim of providing university education to qualified Malawians who were not selected for tertiary education because of limited space in the country's universities. The Centre proposed to make use of a wide range of instructional systems, namely, 'print media, radio, television, multimedia, Internet-based media, and webtechnology' (Mzuzu University 2014). This is in line with typical features of ODL as suggested by Leary and Berge (2007:137) and Chimpololo (2010:68) who postulate that ODL programmes are characterised by a blended learning system that puts an emphasis on print material, some correspondences by mail and communication by radio, text and email and that it depends less on e-learning delivery systems. To expand its operations and increase the intake of ODL students, Gwede (2014) highlights some areas in which MZUNI seeks assistance from well-wishers, especially development partners as follows:

- Linkage with technological organisations so as to access technological services at subsidised rates or secure ICT donations;

- Development of adequate infrastructure for delivering ODL programmes such as setting up Satellite Learning Centres in each of the four political regions of Malawi; and

- Repackaging of print instructional materials into portable audio and visual versions so that learners can listen and view lectures at their pace and convenient time using computers or mobile technologies.

\section{Problem statement and research questions}

Although CODL was established in 2006 (Chimpololo 2010:69; Mzuzu University 2014), ODL programmes have been running since 2011 at MZUNI. The researchers who are also employees at this institution are quite aware that students enrolled for this programme do not attend face-toface lessons except for the mandatory 4-week orientation exercise every semester which takes place on campus. The students also come to write end-of-semester examinations on campus where they are given an opportunity to use the University Library. One may speculate that these students might be using public libraries, which are operated by the Malawi Government through the National Library Services (NLS). Regrettably, Nyali (2009), reports that apart from the main library located in Lilongwe, the NLS has only 11 branches [although Chimpololo (2010:69) puts this figure at 12] spread across the three geographical regions of Malawi. There are four in the South, three in the Centre and four in the North. Considering the fact that these NLS branches are located in towns only and that the majority of ODL students stay in the remotest parts of the country where they spend about 20 weeks per semester doing self-study with very limited or no access to libraries yet information is an indispensable aid to learning [for students], whether oncampus or off-campus' (Boadi \& Letsolo 2004:197), these researchers wonder where these students obtain information for their academic activities. The study seeks to establish how these students access information for their studies, the challenges that they face and how they mitigate them. Specifically, the researchers seek to address the following questions:

- What are the information needs of ODL students?

- What are the information sources of ODL students?

- What are the challenges that ODL students face when seeking information?

\section{Literature review}

Several studies have been conducted to identify the actual information needs of learners enrolled for distance education. For example, writing with specific reference to the Indian context, Jagannathan (1998:140) identifies three principal information needs of students enrolled for ODL programmes. Firstly, ODL students need materials which include reference books, journals, library reading room and Self-Instructional Materials as well as facilities such as library reading rooms. Secondly, she mentions information services such as bibliographic instruction for print and non-print materials and information about distance learning agencies and support service, and finally, she cites user services or user education on library collection, library equipment and facilities available in the library. Although these needs seem to be very appropriate for a campus-based learner where the libraries are located, maybe, the author meant for distance education students who visit the campus once in a whilst as opined by Holmberg (2005:14) that in other cases supplementary faceto-face sessions can be useful for distance education students. Boadi and Letsolo (2004) identify needs such as research projects, examinations and assignments. Students also need core collections, professional library staff and supplementary materials, reference services, user education and library orientation (Commonwealth of Learning 2003; Kascus \& Aguilar 1988). Similarly, Oladokun and Aina (2009) find that 
distance education students at University of Botswana needed information for job opportunities (89\%), career development $(84 \%)$ and information on sponsorship or scholarships for further education $(80 \%)$.

Boadi and Letsolo (2004) found that apart from $64 \%$ of them using the library as a source of information, ODL students sought information from colleagues $(77.8 \%)$, personal collection $(74.1 \%)$, lecturers / experts $(70.4 \%)$, course material $(64.8 \%)$, family members $(53.7 \%)$ and Internet $(22 \%)$. The Internet scored a low percentage maybe because the Internet was not fully developed in 2004 in most African countries. After all, Leary and Berge (2007:139) indicate that Africa has seen remarkable growth in information technology in recent years as compared to 1996 when only 11 African countries had Internet access. However, there is a ray of hope in terms of Internet penetration in Sub-Saharan Africa according to Wilson (2008:9) who argues that the widening availability of mobile phones in rural Sub-Saharan Africa and the increased provision of Internet access will facilitate the adoption of ODL in rural areas. In a study conducted by Sutherland (2000) in the United States targeting ODL students at Western Colorado Graduate Centre, it was found that most learners borrowed information resources from local schools and local public libraries and used online resources. The web-based information sources are reported to be highly used by ODL students according to Kelley and Orr (2003). In United States, Thompson (2007) conducted a study to identify the needs of distance education students at the University of North Carolina and the study revealed that most students preferred electronic resources to traditional print-based resources. The students indicated that they consulted Google more often for information. Because it is understood that the mass media, especially the radio and television, have a capability to reach a wider population of people, they are being used to deliver lessons to ODL students in China (Xing-fu 2001), Ghandi National Open University, Botswana and in most different parts of the world, viz. America, China and University of South Africa in South Africa (Oladokun 2014:308).

Factors that impinge successful implementation of ODL programmes are indicated by some researchers. By investigating the implications of adopting open educational resources for tertiary education at an institution in the United Kingdom as compared to one in South Africa, Wilson (2008) finds that ODL is well developed and supported in the United Kingdom and enjoys sufficient funding, whereas in South Africa, ODL programmes are becoming popular and are increasingly being recognised by the Government and all education stakeholders. Wilson (2008) argues further that the inequalities in educational achievements between developed and developing countries do exist as a result of vastly different levels of funding. In a similar study, Oladokun and Aina (2009) investigated the information needs of part-time or continuing students at the University of Botswana and report that the most common barriers to information sources include lack of well-equipped libraries (55\%), cost of equipment and lack of time (50\%) and 18\% cited lack of technological skills. The challenges or concerns have been studied from students' and instructors' perspectives. Valentine (2014) raises an important point by arguing that not all students are suited to this type of learning and not all subjects are best taught via this medium, though Holmberg (2005:14) is of the view that a wide range of subjects that are said to be 'complicated' such as medicine and surgery have proved to be teachable and learnable through ODL. As stated already, ODL students are separated from their instructors geographically. Such lack of interaction is likely to lead to some problems, especially when different views cannot be resolved through non-verbal cues and further misunderstood or misinterpreted by the learners (Valentine 2014). Such a development can negatively affect the progress of student's lessons. This is the reason West (1994) and Valentine (2014) emphasise the need to provide compressed video that can clearly magnify the strengths and weaknesses of the instructor. Although distance education students enjoy some degree of freedom as compared to traditional mode of learning, the Commonwealth of Learning (2002:73) cites several challenges that ODL students face in their studies which include meeting deadlines for submission of their academic work, doing group work collaboratively, using library facilities to access information technology and preparing for and taking examinations. Unlike the printbased materials, which they are familiar with, ODL students face a challenge of coping with other distance learning strategies or instructional systems such as a combination of interactive audio or video tape materials, television-aided learning, overhead projectors and computer-assisted instruction using the Internet or computer referencing (The Commonwealth of Learning 2002:73). In Malawi, some challenges militating against the smooth implementation of ODL programmes are highlighted by Chimpololo (2010:70) as follows:

- Poor economic growth implying that 'not all people have the potential to meet the demands of ODL such as the purchase of print study materials, purchase of ICT resources like mobile phone handsets and data storage appliances, payment of internet services and payment of tuition and examination fees' (Chaputula 2012; Chawinga 2014; Chimpololo 2010:70);

- Insufficient libraries: The NLS has very few service centres in the 28 districts, which, worse still, do not have adequate information resources to satisfy demand; and

- Unreliable electricity supply: Chimpololo (2010:70) reports that only about $25 \%$ of households in urban areas and about $1 \%$ of rural households have electricity supply. Chimpololo (2010:70) argues that it becomes extremely difficult for ODL students to either study at night or use their ICT appliances during the day.

\section{Data collection methods}

This survey targeted registered ODL students at MZUNI who were enrolled in the following programmes: Bachelor of Arts (Education) and Bachelor of Science (Education). 
Most of the participants are government primary and secondary school teachers who come from similar education systems but are located in different parts of Malawi. The students are quite homogenous in the sense that they all have a Malawi School Certificate of Education (MSCE), which is minimum requirement for selection into any degree or diploma programme offered at MZUNI. Some students are in possession of a Primary School Teaching Certificate, which qualifies them to teach at primary level though because of shortage of teachers in secondary schools in Malawi, some do teach at secondary level with this basic certificate. The students visit the university campus very infrequently. In fact, there are two official periods per semester when students visit the University: during orientation and when they come to write end-of-semester examinations. This is the only time they have a full opportunity to use the University facilities such as the library and Internet services and to interact with the lecturers. Thus, the study was carried out in order to assist MZUNI Management and other stakeholders in understanding a web of issues that surround the information needs of ODL students enrolled with this University.

By self-administering the questionnaire containing a mix of open-ended and closed-ended questions (Powell \& Connaway 2004:146) to students, we were able to gather both qualitative and quantitative data from the students. The total population of ODL students at MZUNI who were in levels two and three was 350. There were no students in levels one and four when the study was being carried out. Being employees of the University, the researchers were quite convinced that all the students had written assignments, tests and end-of-semester examinations, implying that all of them could appreciate the need for information for accomplishing their academic activities. It was practical for researchers to target the current number of students and a questionnaire was sent to all of them. Other than the initial section of personal information, the questionnaire contained three main sections: questions relating to the information needs of the ODL students, questions relating to the sources of information for ODL students and finally questions relating to the challenges that ODL students face in their quest to find information for their studies. Some questions required participants to select from a list of answers provided, whereas others were left open-ended to encourage participants to express their views about their information needs and the challenges they face. We self-administered the questionnaire to and collected from the students. Data were collected in the month of February 2015 when the students came to write end-of-semester of examinations.

\section{Data presentation and discussion Background information}

We sent a questionnaire to 350 students, of whom 258 (73.7\%) responded. Of the 258 respondents, 215 (83.3\%) were men and $43(16.7 \%)$ were women. The low response rate of the women reflects our deeply rooted common cultural practice in Malawi, where girls are expected to stay in homes doing house chores, and traditionally, they marry at a young age and are thus rarely given an opportunity to do their studies up to the university level. The findings further support reports by the World Bank Working Paper (2010:15), which states that female enrolment has remained around 30\% in Malawian public universities. The researchers are satisfied with the response rate, especially taking into account that similar previous studies such as those by Kelley and Orr (2003), McLean and Dew (2004) and Thompson (2007) have registered lower rates with scores of $32 \%, 11 \%$ and $10.5 \%$, respectively.

As can be seen in Figure 1, it is clear that $114(44.2 \%)$ respondents are aged between 21 and 30 followed by 97 (37.6\%) aged between 31 and 40 . The pattern is a result of two probable reasons. In Malawi, the education system follows the 8-4-4 systems, where 8 refers to eight years spent in primary school, whilst the two 4 s refer to the 4 years spent in secondary schools and universities, respectively. Because the de facto starting age for primary education in Malawi is 6 years (minimum) in Government Primary Schools, it is rare to find a 20-year-old or younger Malawian in universities. Secondly, most of respondents did not join the university immediately after completing their secondary education; instead, the majority had to study for the primary school teaching course in various teacher training colleges in Malawi where they spent $2-3$ years. This is evidenced by a huge number of $170(65.9 \%)$ students with certificates in primary school teaching. Some students did not have a chance to be selected to university because of limited space until the ODL programme started at MZUNI. It is thus not surprising that the results show quite clearly that $170(65.9 \%)$ respondents have certificates in primary school teaching and that 179 $(69.4 \%)$ work as government primary school teachers. It is observable that the number of respondents who work as Government Primary School Teachers is numerically greater than the respondents with Primary School Teaching Certificate, which is a prerequisite to teach at primary level in Malawi. We suggest that the inconsistency may mean that some respondents are enrolled with the Teachers Training Colleges and MZUNI through ODL and are simultaneously studying towards the attainment of a Primary School Teaching Certificate and a Bachelors or Diploma, respectively. This might be possible because in the first place, despite both institutions (Teachers Training Colleges and MZUNI) running ODL programmes, they work independently and secondly, as shown in Figure 1, MZUNI enrols students with only MSCE without considering the Primary School Teaching Certificate. Worthy of highlighting as depicted in Figure 1 is that the majority of the respondents are studying for a Bachelor of Arts (Education) with a total of 242 (93.8\%). This is because, according to the findings, most students in Malawi are not interested in science subjects, especially Mathematics and Physical Sciences, which they are expected to excel in their MSCE if they are to be selected into any science or related programmes. A selected verbatim from respondents as to why they chose to study for a Bachelor of 


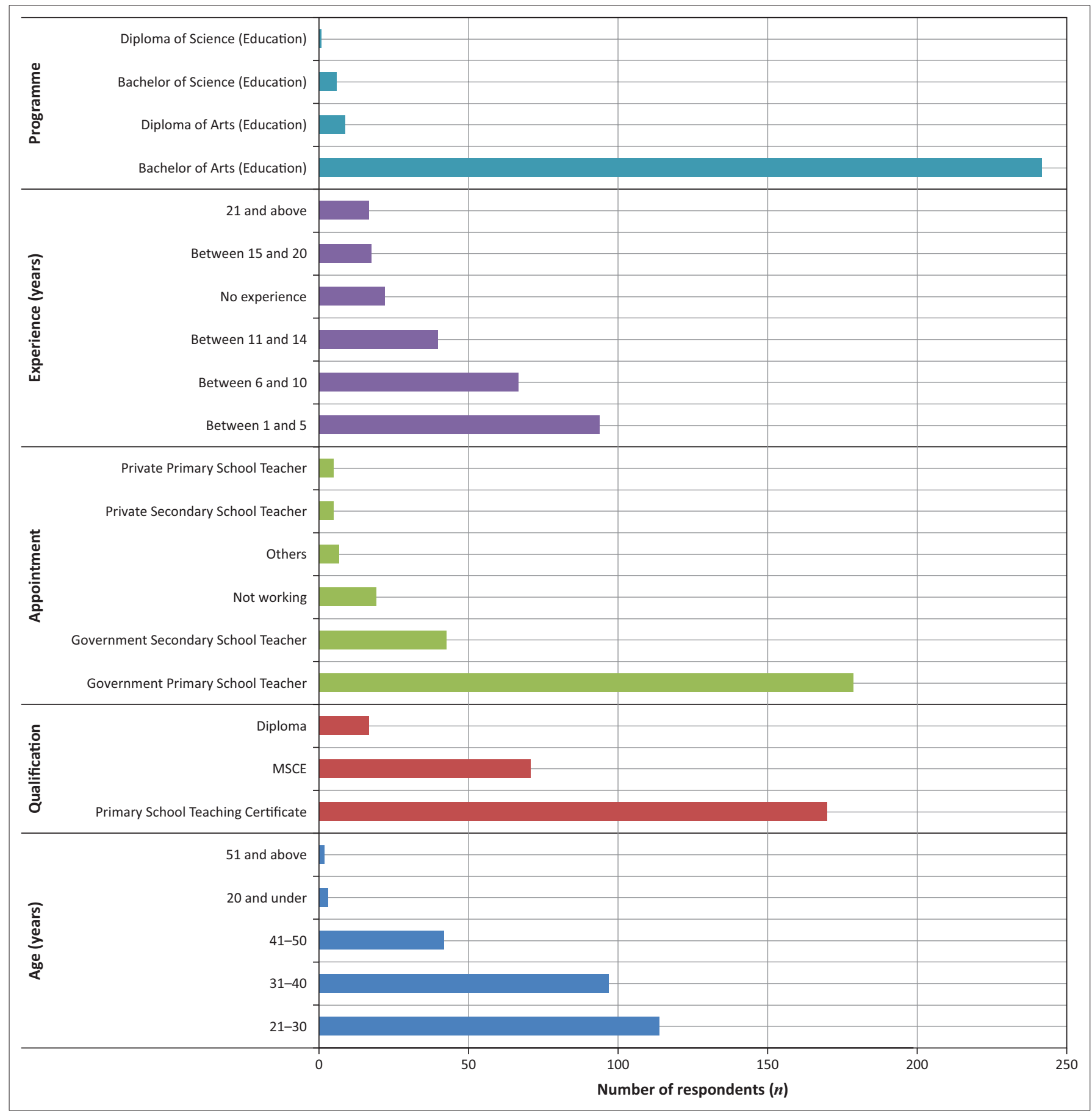

FIGURE 1: Background information of respondents $(n=258)$.

Arts Degree is as follows: 'I scored distinctions in arts subjects at MSCE level', 'because science subjects are tough to me' and 'because my MSCE does not have science subjects.' Thus, although it is the wish of the University to admit many students into Bachelor of Science (Education) programme, it receives very few applicants. The number of students studying for diplomas is smaller because the University does not necessarily admit students to do diplomas. Rather, the University provides an opportunity for students to exit at two points. The students can choose to exit the University when they are in the third year with a diploma or in fifth year (end of programme), where they exit with a bachelor's degree.

\section{Information needs}

In this item, students were provided with a list of the reasons to choose from, for why they needed information as depicted in Table 1 . The question allowed multiple responses. Mainly, Table 1 reveals that 209 (81.6\%) students need information to accomplish their course activities and also for general educational purposes. It is not surprising that students need information for scholarship purposes because most of them are responsible for all expenses such as tuition fees and accommodation and meals when they temporarily come to MZUNI either for orientation or to write end-of-semester examinations. This is in addition to 
TABLE 1: Information needs of the ODL students at MZUNI $(n=258)$.

\begin{tabular}{lcc}
\hline $\begin{array}{l}\text { Reasons for information } \\
\text { need }\end{array}$ & $f$ & $\%$ \\
\hline $\begin{array}{l}\text { Information on subjects } \\
\text { relating to course of study }\end{array}$ & 209 & 81.6 \\
$\begin{array}{l}\text { Information on } \\
\text { sponsorship/scholarship for } \\
\text { further education }\end{array}$ & 168 & 65.6 \\
$\begin{array}{l}\text { Information on further } \\
\text { education after diploma or } \\
\text { degree programme }\end{array}$ & 168 & 65.6 \\
$\begin{array}{l}\text { Information on career } \\
\text { development }\end{array}$ & 84 & 32.8 \\
$\begin{array}{l}\text { Information on job } \\
\text { opportunities }\end{array}$ & 53 & 20.7 \\
$\begin{array}{l}\text { Information for general } \\
\text { purposes (entertainment, } \\
\text { health, weather) }\end{array}$ & 32 & 12.5 \\
\hline
\end{tabular}

Note: Multiple responses were received

the fact that most of them are married and therefore are expected to look after their extended families which is part of the tradition and culture in Malawi. A further analysis of the results show that of the $53(20.7 \%)$ students who need information for job opportunities, 29 (11.2\%) are those that are not working and those working in private primary and private secondary schools.

\section{Educational activities}

As noted in the previous section, the majority of the students need information on various subjects relating to their courses of study. Thus, in this item, we specifically asked the students to indicate the types of educational activities that they accomplish using the information they seek. As can be seen in Figure 2, all (100\%) students need information to prepare for end-of-semester examinations. As already indicated in the previous sections, apart from the assignments that students write when doing their self-study at home, all students are required to come on campus to write end-ofsemester examinations, which contribute $60 \%$ of the final grade of any semester course. Assignments that students write during self-study at home are crucial for ODL students, and this explains the reason why 243 (95.7\%) students said they needed information for this activity. However, it was unexpected for the study to register $70(27.6 \%)$ students who need information for mid-term tests because students do not write such tests. However, in this case, it was a special arrangement where some lecturers who did not administer assignments were given an opportunity to administer 'midterm tests' during the examination preparation period just a week before the end-of-semester examinations as a make-up for the missed assignments. These academic activities are not unique to MZUNI because Boadi and Letsolo (2004) also found that ODL students in Lesotho need information to accomplish academic activities such as research projects, end-of-semester examinations and assignment. Thus, it is logical to suggest that in most scenarios, ODL students do not write mid-term tests.

\section{Information sources}

A mix of closed and open-ended questions were used to collect data about the sources of information that students

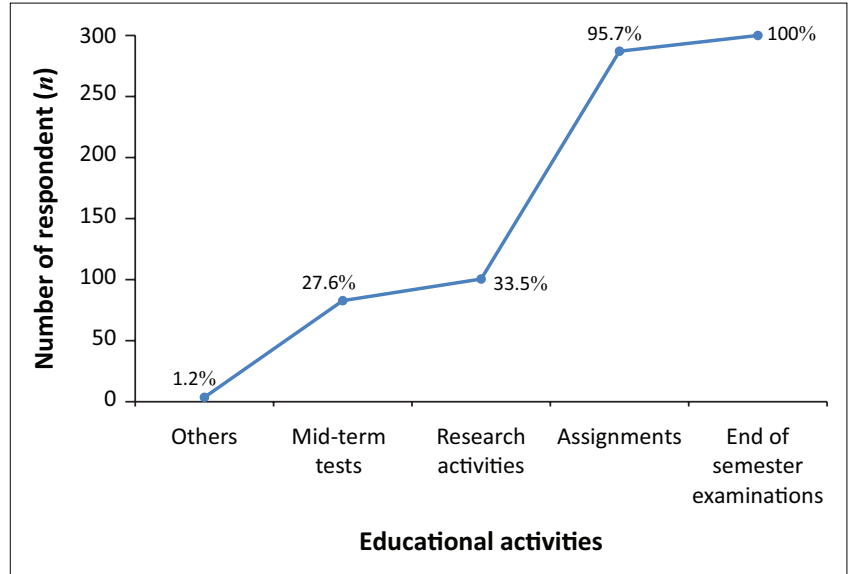

Note: Multiple responses were received

FIGURE 2: Kinds of educational activities accomplished using the needed information $(n=258)$.

use to accomplish their educational activities. The aim was to find out the most used information sources and the ones that are considered to be most important in the accomplishments of academic activities by students. Results presented in Figure 3 show that the information sources that are used most by students include lecture notes, Internet and library books with scores of 238 (92.6\%), $207(80.5 \%)$ and $199(77.4 \%)$, respectively. It is peculiar to observe that most students claim to use lecture notes yet, as already stated in some previous sections, they only attend lectures for less than a month and spend 20 weeks doing home study. We believe that the students do confuse lecture notes with learning manuals (modules) provided by the University. Thus, this explains why university learning manuals scored a meagre $(44.4 \%)$ despite all students being issued with them. It is quite interesting to note that despite most students living in some of the remotest parts of the country, where basic utilities especially electricity which is used to power digital accessories are alarmingly inaccessible, they are able to appreciate the Internet as a source of information. With the proliferation of Internet-enabled phones in Malawi plus affordable data bundles offered by mobile phone network service providers (Chimpololo 2010:70), it is safe to conclude that these students access the Internet via their mobile phones.

Surprisingly, despite MZUNI having visionary plans during the establishment of CODL that television and radio would be used to deliver lessons to ODL students, the results suggest that the University is yet to start using this strategy because as shown in Figure 3, only 16 (6.2\%) students have ever used it as source of information. Paradoxically, the current findings support and contrast other similar studies. For example, the findings of the current study are similar to those by Boadi and Letsolo (2004) in that both studies find that ODL students overwhelmingly use hand-outs by lecturers and learning manuals. However, in contrast, Boadi and Letsolo (2004) found that only $22 \%$ of the ODL 


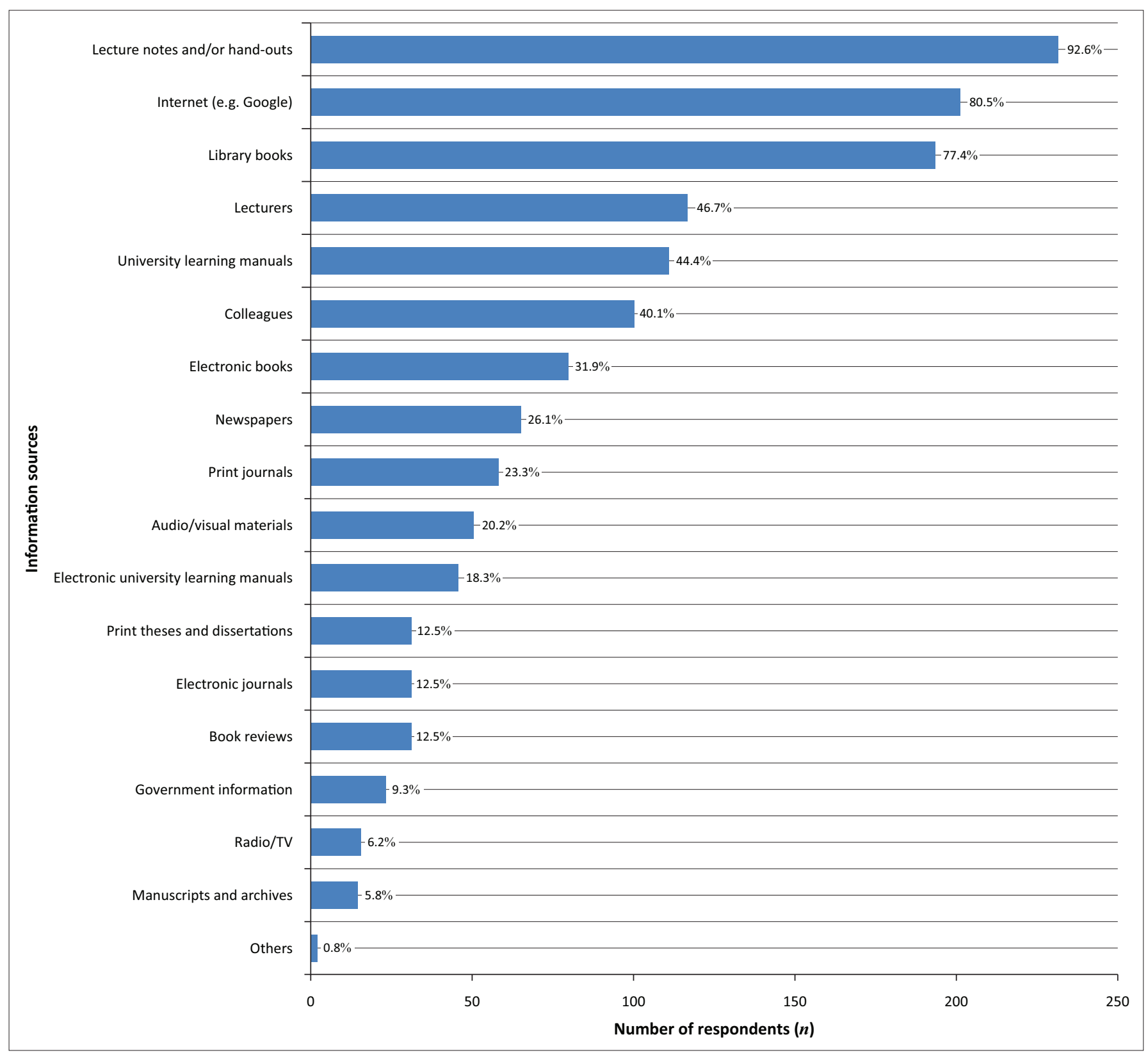

Note: Multiple responses were received

FIGURE 3: Information sources used by students ( $n=258$ ).

students used the Internet in their educational activities. The apparent difference can be attributed to the fact that the study by Boadi and Letsolo (2004) was conducted when the Internet was still in its infancy stage in Africa as supported by Leary and Berge (2007:139), who suggest that Africa only witnessed the growth of the Internet in recent years. The use of Internet may also be attributed to proliferation of Internet-enabled phones, which according to Wilson (2008:9) and Chimpololo (2010:70) have steadily penetrated to most countries in rural Sub-Saharan Africa and have increased provision of Internet access and the adoption of ODL in rural areas.

A follow-up item to the preceding aimed at identifying students' views about the importance of the information sources. To solicit these data, participants were requested to respond to a series of statements on a four-point scale ranging from very important to not important. Although most students did not respond to the question as depicted in Figure 4 , it is clear that the majority of the students with the scores between $132(51.2 \%)$ and $193(74.8 \%)$ are of the view that lecture notes or hand-outs, Internet, library books and lectures are the most important sources of information for accomplishing their academic activities. There are two main reasons why students rate the lecture notes highly, which we believe include the university learning manuals. Firstly, many students in Malawian universities regard lecturers as the best sources of information for the courses they teach. To them, reading lecturer's notes is as good as reading the upcoming examinations. Secondly, ODL students do not have adequate time to access the university library, which contains books for most courses. Thus, use of lecture notes 


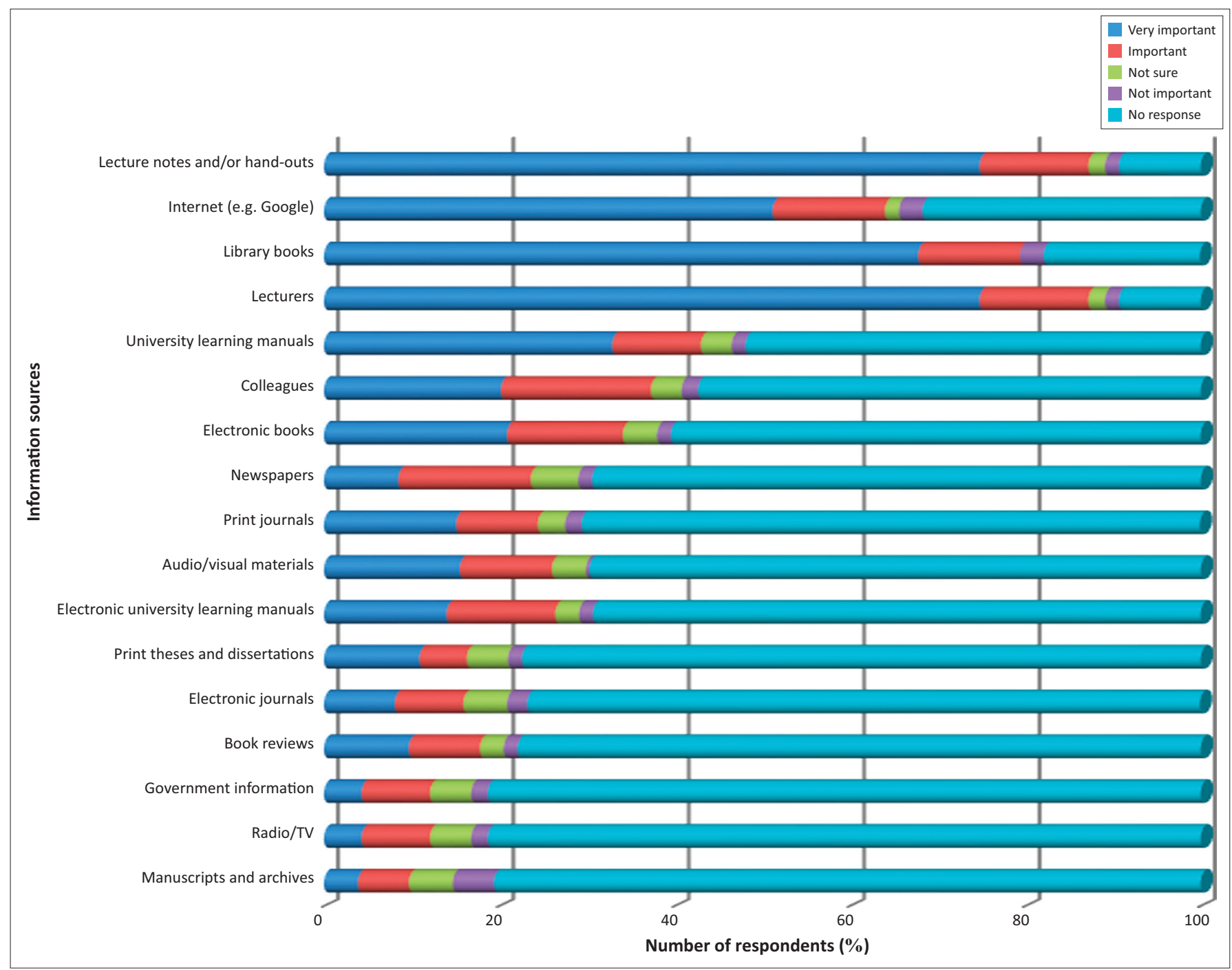

FIGURE 4: Importance of the information sources $(n=258)$.

or hand-outs and university manuals becomes the only available option. On the part of the Internet, two main reasons account for its value. Firstly, the proliferation of the Internet-enabled phones amongst Malawians, a development attributed to the provision of these phones by mobile network service providers at affordable prices (Chimpololo 2010:70). Secondly and more importantly, the study has established that $179(69.4 \%)$ students are employed by the Malawi Government as primary school teachers meaning that they can at least afford to buy Internet-enabled phones and even smartphones. However, the concern is that the Internet is a complex and dynamic landscape full of all sorts of information and it is not clear whether the students possess the ideal information literacy skills to distinguish between good and bad sources of information sourced from the Internet.

Library books are amongst the most valued information sources as can be observed in Figure 4 and students make use of them as main sources of information when they come to write end-of-semester examinations. As a matter of fact, students are given one week to prepare for end-of-semester examinations whilst on campus. Just a week before the data collection exercise for this study started, many students claimed that they used the library books intensively to write supplementary examinations, 'midterm tests' as make up for the missed assignments during the semester and to prepare for end-of-semester examinations. Essentially, it is clear from the findings that MZUNI is so dependent on traditional means in the delivery of lessons to its ODL students. There is no compelling evidence to suggest that MZUNI uses media such as CD-ROMs, electronic manuals and other technological or Internet-based media.

Taking into account that the students stay for 20 weeks at home doing self-study, we also asked them an open-ended question to explain where and how they access information materials that they use for their academic activities when they are not on MZUNI campus. A thematic analysis of the findings is presented in Figure 5. It is apparent that the Internet remains the most used source of information with a score of 201(77.9\%). These results validate the findings in one of the previous sections where it was noted that apart from 


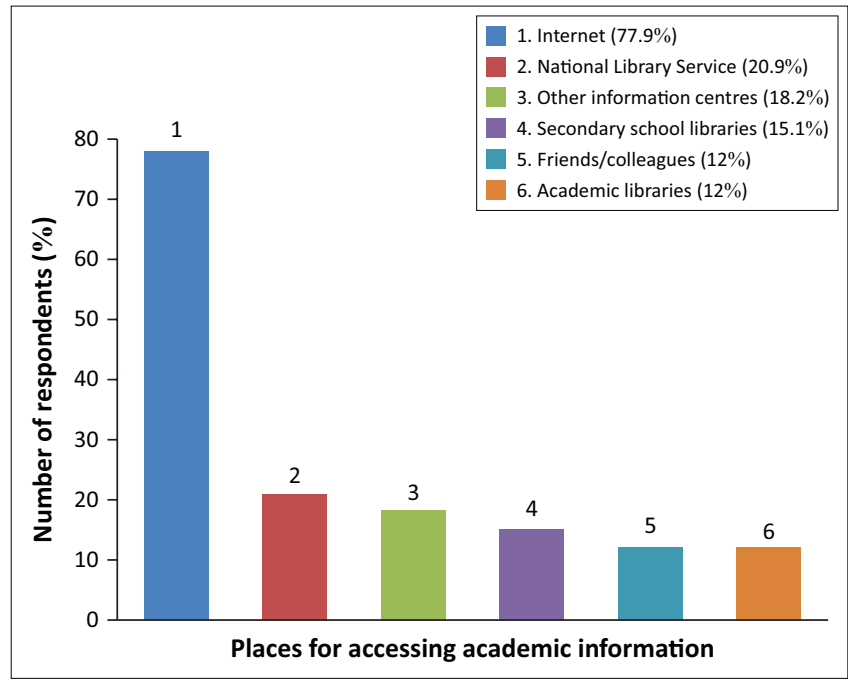

Note: Multiple responses were received

FIGURE 5: Places and ways of accessing academic information $(n=258)$.

lecture notes, $80 \%$ of students use the Internet as their main source of information. A deeper analysis of the results reveals further that students access the Internet using various ways. Most students indicated that they use their basic phones to search information on the Internet. The most used search engines is Google. In fact, it is worth stating that most students do confuse Google with Internet, and interestingly, the term Google is more popular amongst students than Internet. There are three possible reasons for the popularity of Google in this study. Firstly, students do not undergo any formal or informal training in the use of Internet, and secondly, most Internet-enabled phones that are sold in Malawi have Goggle as their default home page and default search engine. Finally, the word searching is interchangeably used as googling in reference to searching any online information regardless of the search engine used. The popularity of Google amongst ODL students as a search engine has also been noted in the United States by Thompson (2007) who reports that ODL students at the University of North Carolina consulted Google more often when searching online information. It is not surprising that students use mobile phones to access the Internet because Chaputula (2012) and Chawinga (2014) independently observe that increasingly Malawians are accessing Internet-enabled phones. A smaller proportion of students also access the Internet in telecentres, Internet cafés and post offices. The results presented in Figure 5 suggest that the NLS, which has a number of branches across the country, is another important source of information for students. Worthy of mentioning is that some students also access the Internet in some of the NLS branches. Although only $20 \%$ of the students use the NLS, we strongly believe that if it can be stocked with relevant information materials, it can make access to academic information convenient to most students. Unlike the NLS, which has its branches located in some cities, towns and districts in the country, we find that most of the places covered in the 'other information category' are mostly located in rural areas where most students live. They include National Initiative for Civic Education, Teacher Development
Centres and telecentres such as Vikwa Telecentre in Kasusngu and community libraries such as Temwa Library in Usisya in Nkhata-Bay. Some of the academic libraries used according to the findings include MZUNI, Zomba Theoretical College, Chancellor College, Seventh Day Adventist University and Livingstonia University, but these constitute a very negligible percentage.

\section{Challenges}

It is widely reported in the literature by several researchers (Chimpololo 2010:70; Commonwealth of Learning 2002:73; Holmberg 2005:14; Oladokun \& Aina 2009; Valentine 2014) that ODL students face a number of challenges when seeking information for their academic activities. In this study, we have found that $252(97.7 \%)$ students face some challenges, whereas $3(1.2 \%)$ said they do not and $3(1.2 \%)$ did not respond to the question. According to the results, 166 (65.8\%) students indicated they lack access to relevant information materials for their courses of study. We believe that the problem results from three main reasons. Firstly, the students live in some of the very remote parts of the country where they cannot manage to travel to access the MZUNI Library to which they are the bona fide members. Worse still, MZUNI has not made any arrangements for the Library to devise a plan on how to make information materials available to ODL students during their 20-week self-study period. Despite subscribing to some information databases such as Emerald, these databases cannot be accessed off-campus. The other reason is that in Malawi, it is rare to find rural libraries (Chimpololo 2010:71; Nyali 2009), which could have been used by the students so much so that most students made comments similar to those made by two of the respondents as follows: 'there are no books to be used for my studies and [Internet] Google search requires money to access information' and 'while at home, I find it difficult to get books which have information since there are no libraries'. Specifically, 63 (25\%) students indicated that there are no information centres where they live. Thus, though it was noted in the previous section that information centres such as National Initiative for Civic Education provide students with some information materials, such centres are far and apart in addition to the fact that they do not contain relevant information materials. In fact, such centres are non-existent in most districts. Another notable challenge is the cost of Internet. Precisely, 96 (38\%) students bemoaned that the Internet is expensive. In Malawi, Internet service providers especially in Internet cafés, which are commonly found in urban areas, charge quite exorbitant user fees. Thus, most students resort to using their basic phones which are considered cheaper because the network service providers in Malawi do provide various data bundles to suit their customers. However, most students indicated that their phones are too basic to access most online information. For example, some students said that their phones could not read PDF files.

Although the Internet has been found to be the only apparent source of information for most students, there is one more concern worth highlighting in regards to its use. 
The results show that $58(23 \%)$ students lack information literacy skills, especially when it comes to retrieving and using information from the Internet. Anecdotal evidence suggests that the Internet is a complex avenue with a wealth of information. However, the challenge is to identify which information is accurate and that is why information literacy skill becomes vital. A comment by one of the students that 'sometimes the information is rejected by lecturers as not accurate, searching information using the Internet is expensive and I am not sure which information I get from the Internet is right or wrong' represents many such comments realised in the study and sums up the complexity in using the Internet as a source of information for ODL students. The findings suggest that these students do not undergo any formal or informal information literacy training. The significance of bibliographic programmes that information professionals are increasingly referring to as information literacy has been emphasised before by Jagannathan (1998) who noted that ODL students in India needed to be equipped with necessary skills for print and non-print materials. However, in the current study, it is the inadequacy in Internet skills that have come out very clearly mainly because unlike the study by Jagannathan (1998) it is understood that the Internet has only proliferated steadily in developing countries in the last decade. A recent study by Oladokun and Aina (2009) found that lack of technological skills stymied students' access to academic information. Thus, the current study together with that of Oladokun and Aina (2009) support claims by the Commonwealth of Learning (2002:73) that ODL students face a challenge of coping with the use of the Internet.

We also asked students to make suggestions about what MZUNI should do to help ease the problems they face when seeking academic information. A thematic analysis of the results shows that $208(80.6 \%)$ students are of the view that MZUNI should introduce satellite information centres in various parts of Malawi, 120 (46\%) want the university to start using the Internet in the delivery of some information materials, 115 (44.5\%) want the University to orient them in using the Internet and computers, and finally, 83 (32.1\%) students want the university teaching manuals/hand-outs to be made more elaborate. The issue of satellite centres has been raised before by Chimpololo (2010:70), who argued that with improved road infrastructure in Malawi, ODL institutions can take advantage of this development to open satellite centres in strategic parts of the country where print and electronic study materials could be accessed by students. Throughout, these findings have been very consistent about the importance and use of the Internet by students. However, it is worrying to note that despite the Internet being found to be the only key source of information by students, most of them lack necessary skills to suitably search and retrieve the right information available on the Internet such that one of the students commented that 'I understand that as much as the Internet has got both, bad and inaccurate information and I find it difficult to distinguish between accurate and inaccurate information'.

\section{Conclusion and recommendations}

According to the findings, it is clear that students need information for quite a number of purposes, which include accomplishing their course activities, scholarship purposes and information on career development. In regards to academic activities, the study has established that specifically, students need information mainly for preparing end-of-semester examinations and for writing assignments. In terms of information sources, we have noted that the university learning manuals (modules) and the Internet are the most used information sources. However, most students lack Internet skills that are necessary for retrieving accurate and reliable information on the Internet. Although access to the Internet is mainly by the use of Internet-enabled phones, other means like Internet cafés are also used but rarely. Several challenges impeding access to academic information have been noted. Firstly, there is lack of information materials such as books and journals that students can use in the accomplishment of their academic activities during their self-study period and there are no information centres in most of the rural areas where the majority of these students live. A synthesis of the findings has led us to make the following recommendations, which we believe if implemented by MZUNI, can help alleviate the challenges that ODL students face:

- The fact that the students cannot access the MZUNI Library for the period of 20 weeks per semester, MZUNI should establish satellite information centres where students can access information materials both in print and electronic format for their courses of study. The Northern Region can have one centre in addition to the MZUNI Library and the Central and Southern regions can have three each;

- Because the NLS has been found to be the only information service provider, which is relatively found in all the cities and in some districts, MZUNI should take initiative to partner with the NLS in the provision of relevant information materials to their students;

- There is need to introduce an Information Literacy course, which amongst others will equip students with ideal skills for identifying accurate, reliable and credible information sourced from both the Internet and print materials and other information sources; and

- Because students are able to access information via the Internet, MZUNI should consider adopting the delivery of information to students using the Internet.

\section{Acknowledgements Competing interests}

The authors declare that they have no financial or personal relationships which may have inappropriately influenced them in writing this article.

\section{Authors' contributions}

W.C. (Mzuzu University) and P.Z. (Mzuzu University) equally contributed to the article conceptually and in the write-up. 


\section{References}

Aslam, M., 2000, 'Education and training for millions: Pedagogical challenges for distance education', Open Learning 15(3), 309-315. http://dx.doi.org/10.1080/713688405

Belkin, N.J. \& Vickery, A., 1985, Interaction in information systems: Library and information research report, The British Library, London.

Boadi, B.Y. \& Letsolo, P., 2004, 'Information needs and information seeking behaviour of distance learners at the Institute of Extra-Mural Studies in Lesotho', Information Development 20(3), 189-199. http://dx.doi.org/10.1177/0266666904046827

Borgman, C.L., 1984, 'Psychological research in human-computer interaction', in M.E. Williams (ed.), Annual Review of Information Science and Technology (ARIST), vol. 19, pp. 33-64.

Chaputula, A.H., 2012, 'State, adoption and use of ICTs by students and academic staf at Mzuzu University, Malawi', Program: Electronic Library and Information Systems 46(4), 364-382. http://dx.doi.org/10.1108/00330331211276477

Chawinga, W.D., 2014, 'The use of Web 2.0 in teaching and learning at Mzuzu University's Faculty of Information Science and Communications, Malawi' Master's thesis, Department of Library and Information Science, University of the Western Cape, Bellville, South Africa.

Chimpololo, A., 2010, 'The prospects and challenges of open learning and distance education in Malawi', World Academy of Science, Engineering and Technology 6, 6-29.

Chisa, K.D., 2006, 'A comparative study of the role of donors in three telecentre projects in Africa', PhD thesis, Department of Information Studies, University of KwaZulu-Natal, Pietermaritzburg, South Africa.

Commonwealth of Learning, 2002, 'Distance education and open learning in SubSaharan Africa: A literature survey on policy and practice', viewed 10 January 2015, from http://www.col.org/resources/publications/Pages/detail.aspx?PID=17

Commonwealth of Learning, 2003, 'Developing library and information services for distance education', viewed 18 December 2014, from http://www.col.org/ colweb/site/pid/3131

Gourley, B. \& Lane, A., 2009, 'Re-invigorating openness at the Open University: The role of open educational resources', Open Learning 24(1), 57-65.

Gwede, H., 2014, 'Challenges, opportunities and priorities for Malawi', viewed 12 December 2014, from www.col.org/about/.../Malawi_Report.pdf

Holmberg, B., 2005, Theory and practice of distance education, Routledge, UK.

Jagannathan, N., 1998, 'Libraries in distance teaching university', in M.K. Jain, P.B. Mangla \& N. Jagannathan (eds.), 50 years library and information services in India, pp. 138-148, Shipra Publications, Delhi.

Kascus, M. \& Aguilar, W., 1988, 'Providing library support to off-campus programmes', College and Research Libraries 49, 29-37.

Kavulya, J.M., 2004, 'Challenges in the provision of library services for distance education: A case study of selected universities in Kenya', African Journal of Library, Archives and Information Science 14(1), 15-28.

Kelley, K.B. \& Orr, G.J., 2003, 'Trends in distant student use of electronic resources: A survey', College \& Research Libraries 64, 176-191. http://dx.doi.org/10.5860/ crl.64.3.176

Kuhlthau, C.C., 1991, 'Inside the search process: Information seeking from the user's perspective', JASIS 42(5), 361-371. http://dx.doi.org/10.1002/(SICI)10974571(199106)42:5<361::AID-ASI6>3.0.CO;2-\#

Leary, J. \& Berge, Z., 2007, 'Successful distance education programs in sub-Saharan Africa', Turkish Online Journal of Distance Education 8(2), 136-145.
Mazza, R. \& Dimitrova, V., 2003, 'Informing the design of a course data visualisation: An empirical study', in 5th International Conference on New Educational Environments, Lucerne, Switzerland, May 26-28, 2003, pp. 215-220.

McLean, E. \& Dew, S.H., 2004, 'Assessing the library needs and preferences of offcampus students: Surveying distance education students, from the Midwest to the West Indies', Journal of Library Administration 41(1/2), 265-302. http://dx. doi.org/10.1300/J111v41n01_20

Mzuzu University, 2014, Mzuzu University Prospectus, Mzuzu University, Mzuzu, Malawi.

Nyali, G.L., 2009, 'Role of National Library Service in the social-economic development of Malawi', viewed 10 December 2014, from http://community.eldis.org/?233@ @.59cfe801!enclosure=.59d0109a\&ad =1

O'Brien, J., 1996, Management information systems: Managing information technology in the networked enterprise, McGraw Hill, Boston.

Ohene, J.B. \& Essuman, S.O., 2014, 'Challenges faced by distance education students of the University of Education, Winneba: Implications for strategic planning', Journal of Education and Training 1(2), 156-176. http://dx.doi.org/10.5296/jet.v1i2.5669

Oladokun, O., 2014, 'The information environment of distance learners: A literature review', Creative Education 5, 303-317. http://dx.doi.org/10.4236/ce.2014.55040

Oladokun, O.S. \& Aina, L.O. 2009, 'Library and information needs and barriers to the use of information sources by continuing education students at the University of Botswana', Information Development 25(1), 43-50. http://dx.doi. org/10.1177/0266666908101263

Powell, R.R. \& Connaway, L.S., 2004, Basic research methods for librarians, 4th edn., Libraries Unlimited, Greenwich.

Sutherland, J., 2000, 'Distance education: Library use among adult distance learners: Its implications for local public and academic libraries', Master's thesis, University of Denver, Colorado.

Teaster, P. \& Blieszner, R., 1999, 'Promises and pitfalls of the interactive television approach to teaching adult development and aging', Educational Gerontology 25(8), 741-754. http://dx.doi.org/10.1080/036012799267477

Thompson, A.J., 2007, 'Information seeking behaviour of distance education students', Master's thesis, School of Information and Library Science, University of North Carolina, Chapel Hill, NC.

Valentine, D., 2014, 'Distance learning: Promises, problems and possibilities' viewed 12 January 2015, from http://www.westga.edu/ distance/ojdla/fall53/ valentine53.html

West, G., 1994, 'Teaching and learning adaptations in the use of interactive compressed video', TH E Journal 21(9), 71-74.

Wilson, T., 2008, 'New ways of mediating learning: Investigating the implications of adopting open educational resources for tertiary education at an institution in the United Kingdom as compared to one in South Africa', The International Review of Research in Open and Distributed Learning 9(1), 1-19.

Wilson, T.D., 1999, 'Models in information behaviour research', Journal of Documentation 55(3), 249-270. http://dx.doi.org/10.1108/EUM0000000007145

World Bank Working Paper, 2010, The education system in Malawi, International Bank for Reconstruction and Development, Washington, DC.

Xing-fù, D., 2001, 'China', in O. Jegede \& G. Shive (eds.), Open and distance education in Asia Pacific Region, Open University of Hong Kong Press, Hong Kong.

Zozie, P.A., Sanga, M.W., Gwayi, S.M., Nyirongo, N.K., Perkins, R.A. \& Lockee, B.B., 2004, Establishment of distance education for secondary school teachers in Malawi, Africa', in M. Orey, M.A. Fitzgerald \& R.M. Branch (eds.), Educational media and technology yearbook 2004, vol. 29, pp. 51-60, Libraries Unlimited, Westport. 